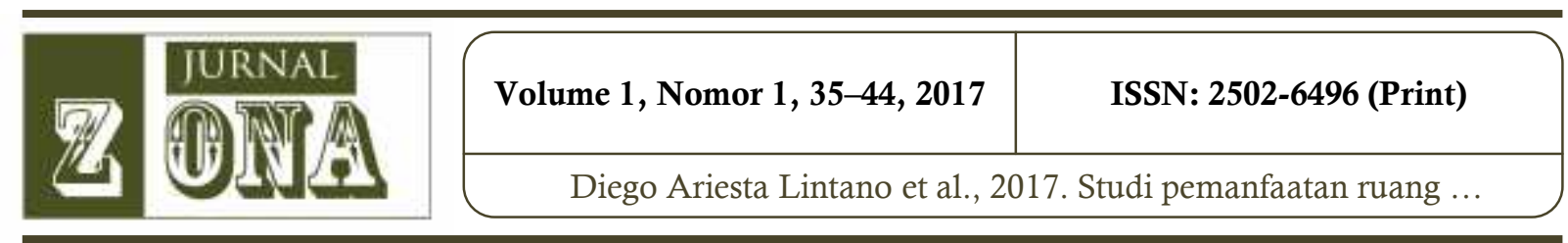

\title{
Studi pemanfaatan ruang dan kejadian banjir di wilayah pesisir Kota Dumai
}

\author{
Diego Ariesta Lintano ${ }^{1}$, Mubarak $^{2}$, Sigit Sutikno ${ }^{3}$ \\ 1, 2 Pascasarjana Ilmu Lingkungan Program Pascasarjana Universitas Riau \\ ${ }^{3}$ Fakultas Teknik Universitas Riau
}

\begin{abstract}
Environmental change due to development processes, such as land clearing and construction of settlements and industries, are belived to cause disruotion of hydrologic conditions, increases level flow and flood peak flow. It happens because of the water absorption capacity at the land surface reduced. The menthod used is frequency analysis to determine the expected local rainfall on various repeated periods and the rain intensity, which are needed for flood flow calculations. The space utilization on economic sector in Sudirman Kota Dumai Rd., are likely to be increased from 2001, 2011, ro 2015. The result of the flood flow $(Q p)$ analysis on 2015 shows tendency to increase on the following years $\left(Q_{\text {existing }}<\right.$ $\left.Q_{\text {prediction }}\right)$. Where as the result of the flood flow $(Q p)$ with catchment well is $Q_{\text {eksisting }}>Q_{\text {scenario. }}$
\end{abstract}

\section{Keywords: Flood, Space Utilization, Catchment well}

Kota Dumai adalah salah satu derah di Indonesia yang sering dilanda banjir. Penyebab banjir di Kota Dumai sangat komplek beberapa diantaranya adalah kondisi topografi Dumai yang tingkat lefelingnya relatif dan dipengaruhi oleh pasang surut air laut. Salah satu daerah yang sering mengalami musibah banjir di Kota Dumai ialah di jalan Sudirman. Daerah ini merupakan pusat kota tempat berbagai aktifitas masyarakat. Pesatnya pembangunan gedung/ruko di jalan Sudirman sejalan dengan meningkatnya perekonomian masyarakat sekitar. Namun kejadian banjir didaerah tersebut telah mempengaruhi aktifitas sosial-ekonomi masyarakat setempat. Sebagai pusat perdagangan, kejadian banjir dapat mengurangi daya beli masyarakat yang berpengaruh pada kurangnya omset penjualan serta pendapatan masyarakat.

Perubahan lingkungan hidup sebagai akibat dari proses pembangunan, berupa pembukaan lahan serta pembangunan pemukiman dan industri diduga mengakibatkan terganggunya kondisi hidrologi, peningkatan aliran permukaan dan debit puncak banjir karena daya serap air pada permukaan tanah berkurang. Untuk dapat mencegah / mengatasi masalah banjir seperti yang telah diuraikan diatas, peneliti tertarik melakukan penelitian tentang "Studi Pemanfaatan Ruang dan Kejadian Banjir diWilayah Pesisir Kota Dumai".

\section{METODE PENELITIAN}

Penelitian ini dilaksanakan pada bulan Maret 2015. Lokasi penelitian berada di Kota Dumai, adapun tempat yang diamati terdapat jalan Sudirman. Alasan pemilihan lokasi karena daerah tersebut terletak di tengah kota dan merupakan pusat perekonomian, didaerah tersebut terdapat titik genangan/banjir yang dapat berpengaruh pada aktifitas sosial-ekonomi masyarakat. Metode penelitian dalam penelitian ini menggunakan metode survei. Sampel diambil dengan teknik purposive sampling yaitu aparat pemerintah dan masyarakat.

Metode analisis yang dilakukan untuk penyelesaian permasalahan ini adalah melalui: data curah hujan, analisis frekuensi, pengujian Chi-Kuadrat dan Smirnov Kolmogorov, intensitas hujan dan debit puncak (Qp) dengan Metode Rasional.

\section{HASIL DAN PEMBAHASAN}

\section{Sistem Drainase Kota Dumai}

Drainase perkotaan adalah sistem drainase dalam wilayah administrasi kota dan daerah perkotaan (urban) yang berfungsi untuk mengendalikan atau mengeringkan kelebihan air permukaan di daerah permukiman yang berasal dari hujan lokal, sungai yang melintas di dalam kota maupun akibat limpasan pasang surut air laut sehingga tidak mengganggu masyarakat dan dapat memberikan manfaat bagi kehidupan manusia. Gambar kondisi saluran drainase Kota Dumai dan daerah studi dapat dilihat pada Gambar 1. 




Gambar 1. Kondisi Saluran Drainase Kota Dumai

Kondisi saluran drainase kota Dumai pada saat ini sebagian besar dalam keadaan mampat / tersumbat dengan adanya endapan lumpur, rumput / tanaman liar yang tumbuh dan sampah yang mengisi dimensi saluran. Menurut Pejabat Pembuat Komitmen (PPK) Pembangunan Drainase Program Pengedalian Banjir Dinas PU Dumai, bahwa kondisi drainase Kota Dumai saat ini tidak terencana dengan matang dikarenakan pembangunan drainase tanpa masterplan. Arah aliran eksisting kota Dumai dapat dilihat pada Gambar 2.



Gambar 2. Arah Aliran Eksisting Kota Dumai

Dari Gambar 2 dapat dilihat arah aliran drainase di wilayah studi mengarah kebagian hilir yang berada di laut. Sebagai wilayah pesisir, arah aliran eksisting Kota Dumai menuju ke laut.

\section{Pemanfaatan Ruang}

Pemanfaatan ruang di wilayah studi terbagi menjadi wilayah pemukiman, perdagangan, perkantoran dan ruang publik (Taman Bukit Gelanggang). Tata guna lahan di wilayah tahun 2001 dapat dilihat pada Tabel 1 .

Tabel 1. Jenis Pemanfaatan Lahan di jalan Sudirman pada Tahun 2001

\begin{tabular}{clrr}
\hline No & Pemanfaatan Lahan & Luas $\left.\mathbf{( m}^{\mathbf{2}}\right)$ & Persentase \\
\hline $\mathbf{1}$ & Perkantoran & $3.357,1$ & $0,8 \%$ \\
$\mathbf{2}$ & Ruko & $27.196,7$ & $6,4 \%$ \\
$\mathbf{3}$ & Rumah & $65.196,7$ & $15,4 \%$ \\
$\mathbf{4}$ & Ruang terbuka & $242.392,6$ & $57,4 \%$ \\
$\mathbf{5}$ & Jalan & $84.494,5$ & $20,0 \%$ \\
Jumlah & & $422.637,6$ & $100 \%$ \\
\hline
\end{tabular}


Dari Tabel 1 dapat dilihat jenis pemanfaatan ruang diwilayah studi pada tahun 2001 didominasi dengan ruang terbuka yaitu $57,4 \%$, ruang terbuka tersebut meliputi tempat parkir, lahan tidak terbangun, halaman rumah dan sebagainya. Pemanfaatan ruang yang diperuntukkan sebagai tempat tinggal/rumah sebesar $15,4 \%$, rumah toko (ruko) sebesar $6,4 \%$ dan pemanfaatan ruang untuk lahan perkantoran sebesar $0,8 \%$. Sisanya pemanfaatan ruang berupa jalan utama sebesar $20 \%$. Berikutnya pemanfaatan lahan di jalan Sudirman untuk tahun 2011 dapat dilihat pada Tabel 2.

Tabel 2. Jenis Pemanfaatan Lahan di jalan Sudirman pada Tahun 2011

\begin{tabular}{clrc}
\hline No & Pemanfaatan Lahan & \multicolumn{1}{c}{ Luas $\left(\mathrm{m}^{2}\right)$} & Persentase \\
\hline 1 & Perkantoran & $5.415,32$ & $1,3 \%$ \\
2 & Ruko & $38.185,97$ & $9,0 \%$ \\
3 & Rumah & $60.561,91$ & $14,3 \%$ \\
4 & Ruang terbuka & $233.979,86$ & $55,4 \%$ \\
5 & Jalan & $84.494,54$ & $20,0 \%$ \\
Jumlah & & $422.637,59$ & $100 \%$ \\
\hline
\end{tabular}

Dari Tabel 2 diketahui bahwa tata guna / pemanfaatan ruang yang ada di wilayah studi pada tahun 2011 di dominasi jenis ruang terbuka dengan persentase 55,4\%. Pemanfaatan ruang sebagai tempat tinggal/rumah sebesar 14,3\%. Kemudian untuk lahan ruko dan perkantoran sebesar 9 dan 1,3\%. Dan pemanfaatan ruang sebesar $20 \%$ digunakan sebagai jalan utama. Bila dibandingkan dengan tahun 2001, persentase pemanfaatan ruang pada tahun 2011 mengalami perubahan pada setiap jenisnya pemanfaatannya, kecuali persentase jenis pemanfaatan ruang pada jalan. Untuk pemanfaatan lahan di wilayah studi tahun 2015 dapat dilihat pada Tabel 3 sebagai berikut.

Tabel 3. Jenis Pemanfaatan Lahan di jalan Sudirman pada Tahun 2015

\begin{tabular}{llcc}
\hline No & Pemanfaatan Lahan & Luas $\left(\mathrm{m}^{2}\right)$ & Persentase \\
\hline 1 & Perkantoran & $5.897,47$ & $1,4 \%$ \\
2 & Ruko & $51.896,46$ & $12,3 \%$ \\
3 & Rumah & $49.075,10$ & $11,6 \%$ \\
4 & Ruang terbuka & $231.274,00$ & $54,7 \%$ \\
5 & Jalan & $84.494,54$ & $20,0 \%$ \\
Jumlah & $422.637,60$ & $100 \%$ \\
\hline
\end{tabular}

Dari hasil survey dan wawancara yang telah dilakukan pada salah satu pegawai negeri sipil Dinas Tata Kota Dumai, pemanfataan lahan di jalan Sudirman sebagai pusat perekonomian didominasi bangunan ruko (rumah toko), pada tahun 2015 sesuai hasil analisis persentase keberadaan ruko meningkat menjadi $12,3 \%$. Begitu juga dengan bangunan perkantoran sebagai akibat dari perkembangan suatu wilayah pembangunan perkantoran meningkat dengan persentase $1,4 \%$.

Untuk pemanfaatan lahan sebagai tempat pemukiman dijalan Sudirman berkurang menjadi 11,6\%. Hal ini disebabkan kondisi wilayah di jalan Sudirman sebagai pusat perekonomian pada saat ini menyebabkan beberapa pemukiman beralih fungsi menjadi rumah toko (ruko) sebagai tempat perdagangan. Sebagian besar pemanfataan lahan pemukiman dibeli oleh pihak pengembang dan kemudian untuk dibangun bangunan baru berupa hotel, ruko dan gedung perkantoran.

Perkembangan yang terjadi diwilayah studi disebabkan perubahan pada pemanfataan ruang/ lahan. Pengertian perubahan guna lahan adalah alih fungsi atau mutasi lahan secara umum menyangkut tranformasi dalam pengalokasian sumber daya lahan dari satu penggunaan ke penggunaan lain (Tjahjati, 1997). Namun, sebagai terminologi dalam kajian-kajian land economics, pengertiannya terutama difokuskan pada proses dialihgunakannya lahan dari lahan pertanian atau perdesaan ke penggunaan nonpertanian atau perkotaan yang diiringi dengan meningkatnya nilai lahan (Wendika et al, 2012). Perubahan penggunaan lahan pada tahun 2001 - 2011 dapat dilihat pada Tabel 4. 


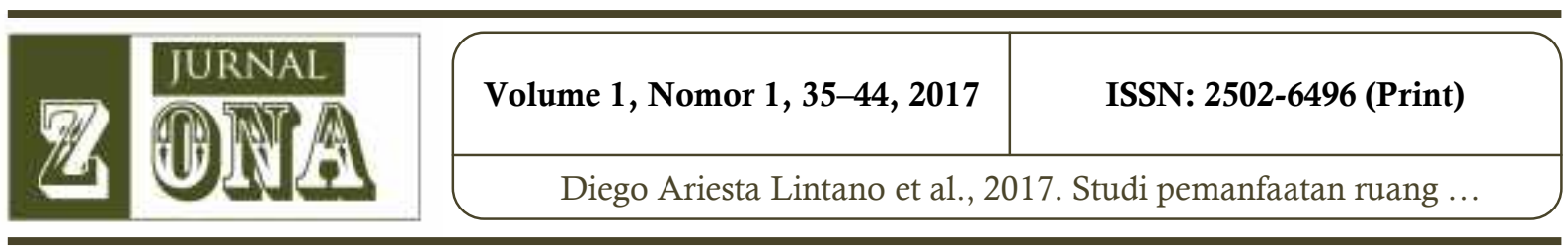

Tabel 4. Perubahan Lahan di Jalan Sudirman Tahun 2001 - 2011

\begin{tabular}{ccccc}
\hline No & $\begin{array}{c}\text { Pemanfaatan } \\
\text { Lahan }\end{array}$ & Tahun 2001 $\left(\mathrm{m}^{2}\right)$ & Tahun 2011 $\left(\mathrm{m}^{2}\right)$ & Perubahan (\%) \\
\hline 1 & Perkantoran & $3.357,1$ & $5.415,32$ & 61 \\
2 & Ruko & $27.196,7$ & $38.185,97$ & 40 \\
3 & Rumah & 65.1967 & $60.561,91$ & -7 \\
4 & Ruang terbuka & $242.392,6$ & $233.979,85$ & -3 \\
5 & Jalan & $84.494,5$ & $84.494,54$ & 0 \\
\hline
\end{tabular}

Perubahan lahan perkantoran dari tahun 2001 hingga 2011 meningkat sebesar 61\%, begitu juga dengan keberadaan rumah toko yang meningkat $40 \%$. Hal ini dikarenakan mulai berkembangnya suatu daerah menjadi pusat kota dengan dibangunnya gedung perkantoran dan pusat perdagangan sebagai kegiatan perekonomian masyarakat setempat. Pembangunan yang didominasi perkantoran dan ruko juga merupakan alih fungsi dari tata guna lahan pemukiman. Hal ini ditandai dengan berkurangnya rumah pemukiman masyarakat di daerah tersebut dengan nilai perubahan $-7 \%$, dan ruang terbuka mengalami perubahan $-3 \%$. Pada saat ini masyarakat memilih daerah pinggiran sebagai tempat tinggal karena harga tanah tidak terlalu tinggi. Selanjutnya untuk tahun 2011 - 2015 perubahan lahan di wilayah studi dapat dilihat pada Tabel 5 .

Tabel 5. Perubahan Lahan di Jalan Sudirman Tahun 2011 - 2015

\begin{tabular}{ccccc}
\hline No & $\begin{array}{c}\text { Pemanfaatan } \\
\text { Lahan }\end{array}$ & Tahun 2011 $\left(\mathrm{m}^{2}\right)$ & Tahun 2015 $\left(\mathrm{m}^{2}\right)$ & Perubahan (\%) \\
\hline 1 & Perkantoran & $5.415,32$ & $5.897,47$ & 9 \\
2 & Ruko & $38.185,97$ & $51.896,46$ & 36 \\
3 & Rumah & $60.561,91$ & $49.075,10$ & -19 \\
4 & Ruang terbuka & $233.979,86$ & $231.274,00$ & -1 \\
5 & Jalan & $84.494,54$ & $84.494,54$ & 0 \\
\hline
\end{tabular}

Dari Tabel persentase perubahan tata guna lahan di jalan Sudirman tahun 2011 hingga 2015 terjadi peningkatan pemanfataan lahan untuk kawasan perkantoran dan perdagangan (ruko), persentase perubahan mencapai $9 \%$ dan $36 \%$. Sementara itu persentase perubahan tata guna lahan pemukiman menunjukkan nilai negatif (pengurangan) yang signifikan dari tahun sebelumnya yaitu - $19 \%$ dan untuk ruang terbuka dengan nilai perubahan $-1 \%$. Lahan di sekitar jalan Sudirman dipandang mempunyai nilai ekonomi tinggi dan berlokasi strategis untuk kegiatan perkantoran dan perdagangan karena letaknya berada di pusat kota Dumai.

Menurut Affan F. M, (2014), bentuk dari penggunaan lahan yang semakin meluas dari yang diperuntukan sebagai pemukiman ataupun sebagai industri itu sangat berbanding lurus dengan kebutuhan manusiawi sebagai makhluk yang memperlukan tempat tinggal dan pekerjaan sebagai penunjang kehidupan sosial masyarakat. Dengan laju pertumbuhan penduduk maka secara otomatis akan memacu pertumbuhan penggunaan lahan yang sebelumnya kosong/tak terpakai hanya sebagai ladang atau sawah dikemudian akan menjadi permukiman ataupun industri.

\section{Koefisien Aliran Permukaan (C)}

Perubahan tata guna lahan tersebut dapat berpengaruh pula pada peningkatan aliran permukaan dan debit puncak banjir. Menurut Pakpahan, Y. C. L. et al, (2012), nilai koefisien aliran permukaan berkisar antara 0 hingga 1 . Nilai koefisien aliran permukaan yang besar menunjukkan bahwa lebih banyak air hujan yang menjadi aliran permukaan. Penentuan harga koefisien $C$ ini juga tergantung pada sifat dan kondisi tanah. Hasil perhitungan koefisien aliran permukaan (C) pada tahun 2001 di jalan Sudirman dapat dilihat pada Tabel 4 . 


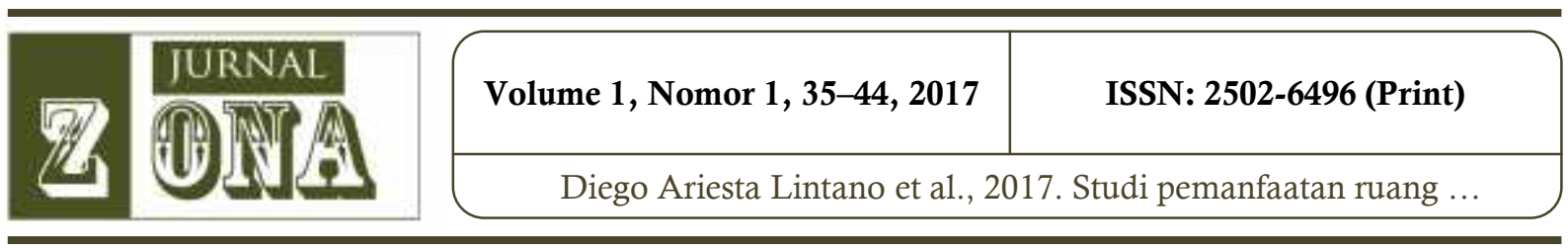

Tabel 6. Koefisien Aliran Permukaan (C) Tahun 2001

\begin{tabular}{clrrr}
\hline No & Pemanfaatan Lahan & Luas $\left.\mathbf{( m}^{2}\right)$ & Koefisien C & \multicolumn{1}{c}{ C x A } \\
\hline $\mathbf{1}$ & Perkantoran & $3.357,1$ & 0,80 & $2.685,65$ \\
$\mathbf{2}$ & Ruko & $27.196,7$ & 0,80 & $21.757,34$ \\
$\mathbf{3}$ & Rumah & $65.196,7$ & 0,52 & $33.902,27$ \\
$\mathbf{4}$ & Ruang terbuka & $242.392,6$ & 0,80 & $193.914,10$ \\
$\mathbf{5}$ & Jalan & $84.494,5$ & 0,82 & $69.285,52$ \\
Jumlah & $422.637,6$ & & $318.551,04$ \\
Koef C & & & 0,761 \\
\hline
\end{tabular}

Dari data luas pemanfaatan lahan tahun 2001 didapat nilai koefisien aliran permukaan (C) yaitu 0,761. Pada wilayah studi penentuan nilai koefisien aliran permukaan $C$ berbeda sesuai dengan kondisi permukaan tanah atau kemampuan air meresap dalam tanah. Untuk koefisien aliran permukaan tahun 2011 di wilayah studi dapat dilihat pada Tabel 7.

Tabe1 7. Koefisien Aliran Permukaan (C) Tahun 2011

\begin{tabular}{clrcr}
\hline No & Pemanfaatan Lahan & Luas $\left(\mathrm{m}^{2}\right)$ & Koefisien C & \multicolumn{1}{c}{ C x A } \\
\hline 1 & Perkantoran & $5.415,32$ & 0,80 & $4,332.26$ \\
2 & Ruko & $38.185,97$ & 0,80 & $30,548.78$ \\
3 & Rumah & $60.561,91$ & 0,52 & $31,492.19$ \\
4 & Ruang terbuka & $233.979,86$ & 0,80 & $187,183.89$ \\
5 & Jalan & $84.494,54$ & 0,82 & $69,285.50$ \\
Jumlah & & $422.637,60$ & & $319.941,51$ \\
Koef C & & & 0,764 \\
\hline
\end{tabular}

Koefisien aliran permukaan (C) pada tahun 2011 yaitu 0,764. Nilai ini meningkat dari tahun 2001 dikarenakan berkembangnya kawasan perkotaan, selalu diikuti dengan berkurangnya daerah resapan air hujan. Selanjutnya koefisien aliran permukaan untuk tahun 2015 dapat dilihat pada Tabel 8.

Tabel 8. Koefisien Aliran Permukaan (C) Tahun 2015

\begin{tabular}{clrcr}
\hline No & Pemanfaatan Lahan & Luas $\left(\mathrm{m}^{2}\right)$ & Koefisien C & \multicolumn{1}{c}{ C x A } \\
\hline 1 & Perkantoran & $5.897,47$ & 0,80 & $4.717,98$ \\
2 & Ruko & $51.896,46$ & 0,80 & $41.517,17$ \\
3 & Rumah & $49.075,10$ & 0,52 & $25.519,05$ \\
4 & Ruang terbuka & $231.274,00$ & 0,80 & $185.019,20$ \\
5 & Jalan & $84.494,54$ & 0,82 & $69.285,52$ \\
Jumlah & & $422.637,60$ & & $323.387,50$ \\
Koef C & & & & 0,771 \\
\hline
\end{tabular}

Koefisien aliran permukaan pada tahun 2015 yaitu 0,771. Dari data tersebut nilai koefisien $C$ pada tahun 2001, 2011 hingga 2015 cenderung meningkat. Hal ini disebabkan karena bertambahnya luas pemanfaatan lahan yang terdapat di wilayah studi. Perkembangan koefisien aliran permukaan dari tahun 2001 hingga tahun 2011 pada jalan Sudirman ialah 0,4 \%. Pada tahun 2011 hingga 2015 perkembangan berdasarkan koefisien aliran permukaan meningkat sebesar 0,9\%. Menurut Soplanit, $\mathrm{R}$ dan Silahooy, $\mathrm{Ch}$ (2012), dengan meningkatnya aliran permukaan maka semakin sedikit air yang dapat di retensi oleh tanah, akibatnya semakin besar jumlah curah hujan yang menjadi debit. Debit akan semakin tinggi di musim hujan dan semakin rendah di musim kemarau karena berkurangnya pengisian air bawah tanah.

\section{Analisis Hidrologi}

Analisis dilakukan terhadap data hujan harian antara tahun 2002 - 2012 (11 tahun) yang diperoleh dari BMKG Dumai. Rekapitulas hasil perhitungan curah hujan pada metode distribusi statistik Log normal, Gumbel dan Log person III yang diuji dapat dilihat pada Tabel 9. 


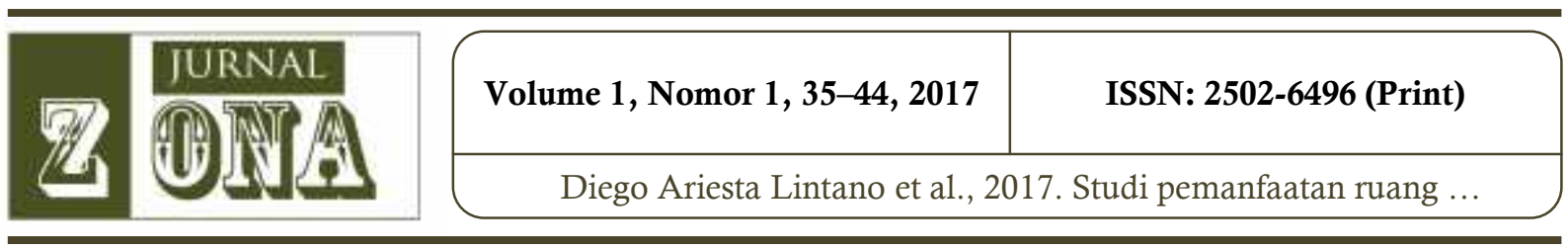

Tabel 9. Rekapitulasi Curah Hujan Rencana

\begin{tabular}{ccccc}
\hline No & Periode & Log normal & Gumbel & Log person III \\
\hline 1 & 2 & 106.55 & 103.996 & 103.872 \\
2 & 5 & 122.15 & 125.748 & 119.586 \\
3 & 10 & 130.32 & 140.147 & 129.309 \\
4 & 50 & 144.62 & 171.846 & 149.544 \\
5 & 100 & 149.82 & 185.246 & 157.790 \\
\hline
\end{tabular}

Dari hasil perhitungan analisis curah hujan rata-rata dapat $C s=0.51$ dan $C k=-0.89$, maka distribusi yang digunakan adalah log Person III karena hasil $C s$ dan $C k$ dianggap paling mendekati. Perbandingan nilai $C s$ dan $C k$ dapat dilihat pada Tabel 10

Tabel 10. Analisa Nilai Distribusi

\begin{tabular}{|c|c|c|c|}
\hline Jenis Distribusi & Persyaratan & Hasil Hitungan & Keterangan \\
\hline \multirow{2}{*}{ Log Normal } & $\mathrm{Cs}=3 \mathrm{Cv}+\mathrm{Cv} 2=3$ & 0.51 & $\begin{array}{c}\text { Tidak } \\
\text { Memenuhi }\end{array}$ \\
\hline & $\mathrm{Ck}=5.383$ & -0.89 & $\begin{array}{c}\text { Tidak } \\
\text { Memenuhi }\end{array}$ \\
\hline \multirow[t]{2}{*}{ Gumbel } & Cs $\leq 1,1396$ & 0.51 & $\begin{array}{c}\text { Tidak } \\
\text { Memenuhi }\end{array}$ \\
\hline & $\mathrm{Ck} \leq 5,4002$ & -0.89 & $\begin{array}{c}\text { Tidak } \\
\text { Memenuhi }\end{array}$ \\
\hline Log Person III & $\begin{array}{l}\qquad s \neq 0 \\
\text { selain dari nilai di atas }\end{array}$ & 0.51 & Memenuhi \\
\hline
\end{tabular}

Penggunaan metode distribusi Log Person III dalam perhitungan curah hujan dianggap paling mendekati/ memungkinkan terjadi dan telah memenuhi persyaratan. Pemeriksanaan uji kesesuaian terhadap distribusi Log Person III dapat dilakukan dengan uji Chi Square dan uji Smirnov Kolmogorov (Soewarno, 1995. Uji Chi Square didapat hasil $\mathrm{X}^{2}$ hit $(1,55)<\mathrm{X}^{2} \mathrm{cr}(7,815)$, maka hipotesa yang diuji dapat diterima. Dan uji Smirnov Kolmogorov didapat hasil $\mathrm{D}_{\text {maks }} 0,183<\mathrm{Do}_{\text {kritis }} 0,391$, maka metode sebaran $\log$ Person III yang diuji dapat diterima. Hal Ini berarti kebenaran/ kecocokan antara hasil pengamatan dengan model distribusi yang diharapkan atau yang diperoleh secara teoritis dapat diterima.

\section{Intensitas Curah Hujan}

Hasil perhitungan curah hujan rata-rata yang telah dilakukan, selanjutnya akan didapat nilai intensitas hujan yang disajikan pada Tabel 11

Tabel 11. Intensitas Curah Hujan

\begin{tabular}{rccccccc}
\hline & R2 & R5 & R10 & R25 & R50 & R100 \\
$\mathrm{T}$ & 103.87 & 119.59 & 129.31 & 165.74 & 149.54 & 157.79 \\
\cline { 2 - 7 } & \multicolumn{6}{c}{$(\mathrm{mm} /$ jam $)$} \\
\hline 1 & 36.010 & 41.460 & 44.829 & 57.459 & 51.843 & 54.703 \\
2 & 22.685 & 26.118 & 28.241 & 36.197 & 32.659 & 34.461 \\
3 & 17.312 & 19.932 & 21.552 & 27.623 & 24.923 & 26.298 \\
4 & 14.290 & 16.453 & 17.791 & 22.803 & 20.574 & 21.709 \\
5 & 12.315 & 14.179 & 15.331 & 19.651 & 17.730 & 18.708 \\
6 & 10.906 & 12.556 & 13.577 & 17.402 & 15.701 & 16.567 \\
7 & 9.841 & 11.330 & 12.251 & 15.702 & 14.167 & 14.949 \\
8 & 9.002 & 10.365 & 11.207 & 14.365 & 12.961 & 13.676 \\
9 & 8.323 & 9.582 & 10.361 & 13.280 & 11.982 & 12.643 \\
10 & 7.758 & 8.932 & 9.658 & 12.379 & 11.169 & 11.785 \\
\hline
\end{tabular}

Dari Tabel 11 penentuan intensitas hujan atau intensity frequency curve (IDF) menunjukkan hubungan antara lamanya hujan (durasi) dengan intensitas hujan menurut kala ulang 2, 5, 10, 50, dan 100 tahun. Intensitas hujan adalah tinggi atau kedalaman air hujan per satuan waktu. Semakin semakin lama durasi 


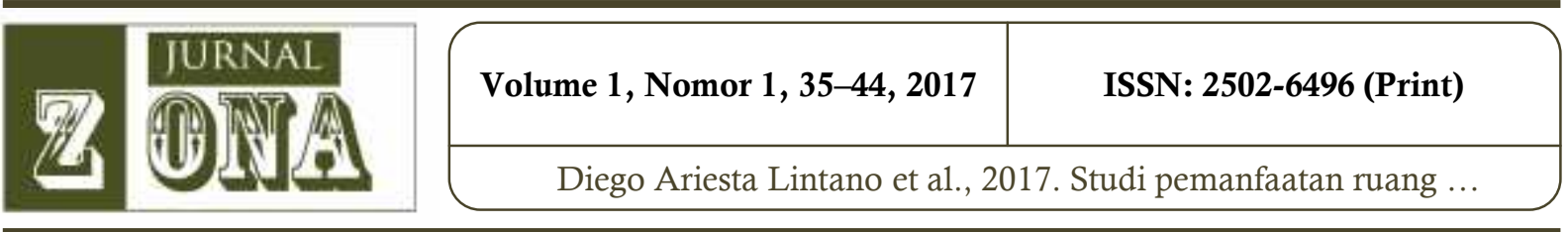

hujan semakin kecil intensitas air hujan. Untuk membuat lengkung intensitas hujan diperlukan beberapa data hujan sebagai mana Gambar 3.

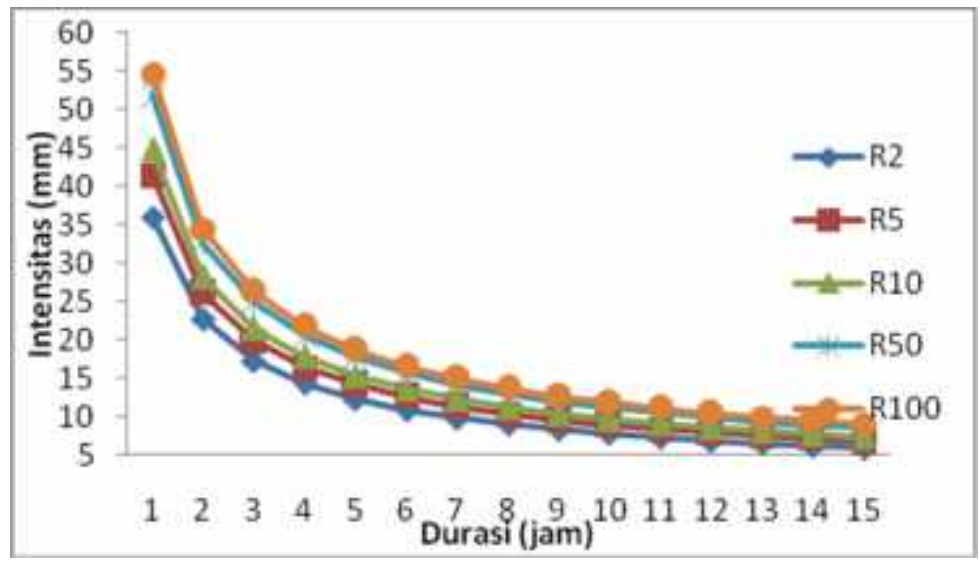

Gambar 3. Kurva IDF Jalan Sudirman

Dari Gambar 3 dapat dijelaskan sifat umum hujan yaitu makin singkat hujan berlangsung intensitasnya cenderung makin tinggi dan makin besar kala ulangnya makin tinggi pula intensitasnya. Hubungan antara intensitas, lama hujan, dan frekuensi hujan dinyatakan dalam lengkung IDF (IntensityDuration-Frequency Curve). Diperlukan data hujan jangka pendek, misalnya 5, 10, 30 menit dan jam-jaman untuk membentuk lengkung IDF (Handayani, Y.L. et al, 2007).

\section{Perhitungan Debit Banjir}

Hasil perhitungan debit banjir rencana akan dibandingkan dengan kapasitas existing drainase untuk menentukan mampu atau tidaknya suatu drainase menampung debit banjir. Perencanaan dimensi lebar dan tinggi pada drainase rencana yang terletak di jalan Sudirman tidak mencukupi untuk menampung debit banjir rencana $\left(\mathrm{Q}_{\text {eksisting }}<\mathrm{Q}_{\text {rencana }}\right)$. Perbandingan debit banjr eksisting dan rencana dapat dilihat pada Gambar 4.

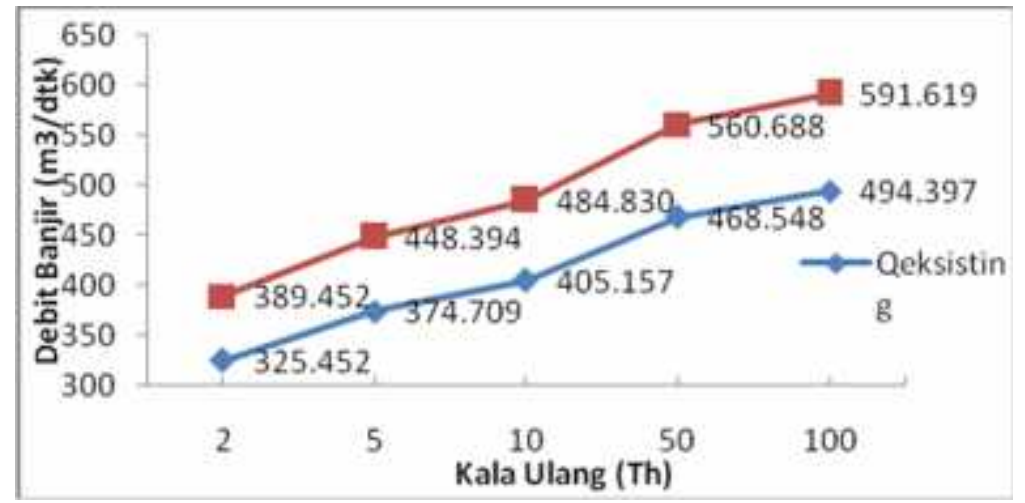

Gambar 4. Perbandingan Debit Banjir Eksisting dan Rencana

Dari Gambar 4, debit banjir saat ini ( $\left.\mathrm{Q}_{\text {eksisting }}\right)$ menunjukkan nilai yang lebih kecil dari debit banjir teori dengan kala ulang 2, 5 10, 50 dan 100 tahun $\left(\mathrm{Q}_{\text {rencana }}\right)$. Hal ini menyebabkan kejadian banjir selalu terjadi diwilayah studi. Nilai yang sebaiknya ialah besarnya debit banjir rencana dengan kala ulang (waktu hipotetik) 2, 5, 10, 50 dan 100 tahun bernilai sama atau lebih kecil dari debit banjir saat ini ( $\left.Q_{\text {eksisting }}\right)$ agar drainase dapat menampung debit banjir dengan optimal.

\section{Kejadian Banjir Kota Dumai}

Permasalahan banjir yang dihadapi terkait dengan pengelolaan drainase perkotaan di Kota Dumai sebagai berikut :

1. Perencanaan dan pelaksanaan pembangunan saluran drainase yang sepotong - potong / tidak menyeluruh sehingga banyak saluran drainase yang tidak optimal fungsinya.

2. Arah aliran air yang tidak jelas karena di beberapa tempat elevasi bagian hilir saluran yang lebih tinggi. 


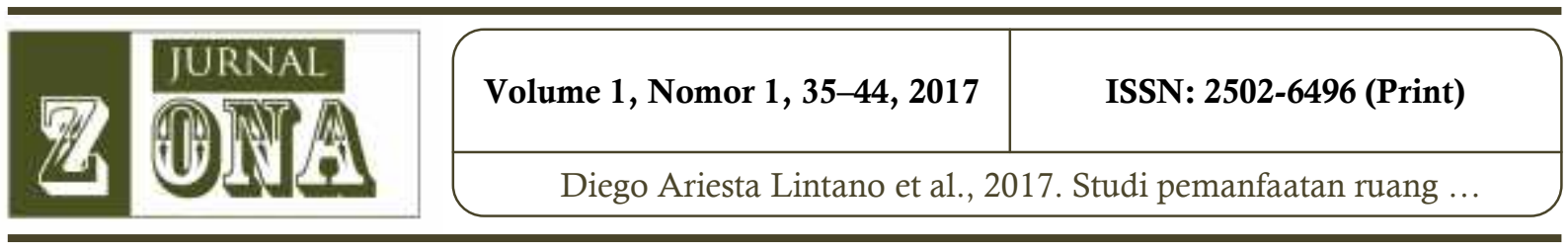

3. Banyak saluran drainase yang sudah tersumbat dan adanya reklamasi di ujung drainase sehingga membuat saluran drainase tersebut tersumbat serta mengalami pendangkalan sehingga tidak mampu lagi untuk mengalirkan air ke tempat pembuang akhir, contoh nya di jalan Sudirman.

4. Kapasitas saluran yang lebih kecil dari kebutuhan pengalirannya.

5. Berkurangnya resapan air pada areal pemukiman.

6. Sikap dan cara hidup masyarakat yang masih belum peduli terhadap kebersihan lingkungan.

\section{Analisis Hidrologi Terkait Tata Ruang}

Pertumbuhan perkotaan yang cepat, terutama yang terjadi di kota besar ditandai dengan makin tersebarnya pusat-pusat kegiatan sosial ekonomi. Secara fisik pertumbuhan perkotaan tersebut terlihat dari perubahan tata guna lahan. Misalnya lahan pertanian berubah menjadi lahan permukiman yang tidak hanya berfungsi sebagai tempat tinggal penduduk, namun pada akhirnya di ikuti pula dengan tumbuhnya kegiatan sosial-ekonomi. Selanjutnya pertumbuhan ekonomi, perubahan pendapatan dan konsumsi juga merupakan faktor penyebab perubahan tata guna lahan. Sebagai contoh, meningkatnya kebutuhan akan ruang tempat hidup, transportasi dan tempat rekreasi akan mendorong terjadinya perubahan tata guna lahan. Akibatnya, lahan basah yang sangat penting dalam fungsi hidrologis dan ekologis semakin berkurang yang pada akhirnya meningkatkan peningkatan erosi tanah dan kerusakan lingkungan lainnya. Konsekuensi lainnya adalah berpengaruh terhadap ketahanan pangan yang berimplikasi semakin banyaknya penduduk yang miskin (Widayanti R, 2010).

Pada wilayah studi perencanaan pembangunan daerah juga tidak terkoordinir dengan baik sehingga kebanyakan drainase penggunaanya tidak optimal lagi serta desain drainase yang tidak sesuai dengan daerah tangkapan air yang melewati saluran tersebut. Beberapa kebijakan yang dapat dilakukan untuk pemulihan kualitas aliran saluran drainase di jalan sudirman dapat dilakukan dengan berbagai cara diantaranya :

1. Keterpaduan penanganan pengendalian banjir oleh instansi terkait (Pekerjaan Umum dan Tata Ruang).

2. Mengoptimalkan pengelolaan prasarana dan sarana sistem drainase yang ada oleh pemerintah, swasta maupun masyarakat dan kemudian melakukan pemeliharaan, pengembangan dan pembangunan sistem baru yang efektif, efisien dan berkelanjutan.

3. Meningkatkan pelayanan publik, sosialisasi kepada masyarakat tentang pentingnya kepedulian terhadap lingkungan.

\section{Sistem Drainase Berwawasan Lingkungan}

Berdasarkan pengertian konservasi air yaitu upaya untuk memasukkan air ke dalam tanah dalam rangka pengisian air tanah, baik secara alami (natural recharge) atau secara buatan (artificial recharge), maka tujuan konservasi air adalah mencari besarnya laju infiltrasi pada suatu daerah dalam rangka pengisian air tanah. Apabila kegiatan konservasi air berjalan dengan baik, maka limpasan permukaan atau genangan air sedikit sekali terjadi. Oleh karena itu, dalam perencanaan sistem drainase berbasis konservasi air yaitu dengan cara menggunakan desain buatan (artificial recharge) pada prasarana sistem jaringan dainase dapat berupa sumur resapan pada tiap-tiap rumah penduduk (Rachman, R. A. et al, 2014).

Salah satu fungsi sumur resapan adalah sebagai upaya menekan banjir. Sumur resapan mampu memperkecil aliran permukaan (Koefisien C) sehingga terhindar dari penggenangan aliran permukaan secara berlebihan yang menyebabkan banjir. Asumsi besaran debit banjir bila setiap bangunan memiliki sumur resapan dapat memperkecil aliran permukaan. Analisis harga koefisien $C$ dapat dilihat pada Tabel 12

Tabel 12. Koefisien Aliran Permukaan (C) di jalan Sudirman dengan Menggunakan Sumur Resapan

\begin{tabular}{ccccc}
\hline No & Pemanfaatan Lahan & Luas $\left(\mathrm{m}^{2}\right)$ & Koef C & C x A \\
\hline 1 & Perkantoran & $5.897,47$ & 0,70 & $4.128,23$ \\
2 & Ruko & 51896,46 & 0,70 & $36.327,52$ \\
3 & Rumah & $49.075,10$ & 0,42 & $20.611,54$ \\
4 & Ruang terbuka & $231.274,00$ & 0,70 & $161.891,80$ \\
5 & Jalan & $84.494,54$ & 0,72 & $60.836,07$ \\
& Jumlah & $422.637,60$ & & $283.795,80$ \\
& \multicolumn{2}{c}{ Koef C } & & 0,671 \\
\hline
\end{tabular}




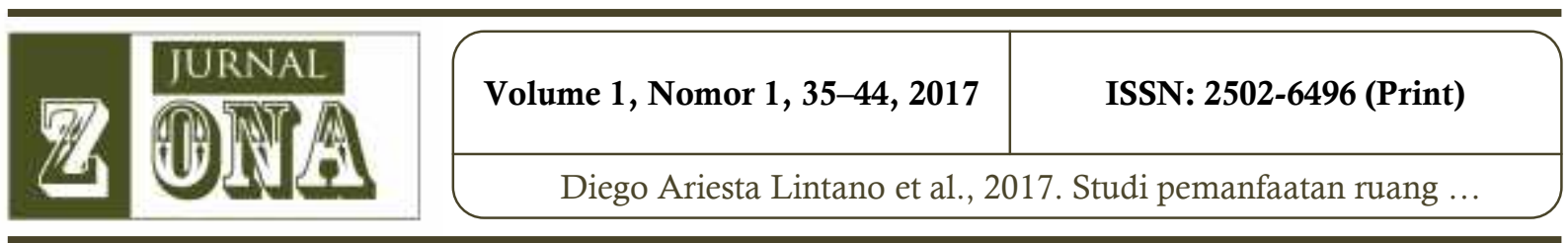

Nilai koefisien aliran permukaan (C) dengan menggunakan sumur resapan adalah 0,671. Nilai koefisien aliran permukaan (C) diwilayah studi bila menggunakan sumur resapan lebih kecil. Hasil perhitungan debit banjir setelah menggunakan sumur resapan dapat dilihat pada Tabel 13.

Tabel 13. Asumsi Debit Banjir

\begin{tabular}{clrrrr}
\hline No & Periode & A (ha) & C & $\mathrm{I}(\mathrm{mm} / \mathrm{jam})$ & $\mathrm{Qt}\left(\mathrm{m}^{3} / \mathrm{dt}\right)$ \\
\hline 1 & 2 & 42,2 & 0,671 & 36,01 & 283,240 \\
2 & 5 & 42,2 & 0,671 & 41,46 & 326,108 \\
3 & 10 & 42,2 & 0,671 & 44,82 & 352,607 \\
4 & 50 & 42,2 & 0,671 & 51,84 & 407,779 \\
5 & 100 & 42,2 & 0,671 & 54,70 & 430,272 \\
\hline
\end{tabular}

Kecilnya koefisien aliran permukaan juga berpengaruh pada berkurangnya debit banjir. Bila dibandingkan debit banjir eksisting lebih besar dari debit banjir dengan menggunakan sumur resapan. Perbandingan debit banjir tersebut dapat dilihat pada Gambar 5.



Gambar 5. Perbandingan Debit Banjir Eksisting dan Debit Banjir Sumur Resapan

Dari Gambar 5 dapat dilihat $\mathrm{Q}_{\text {eksisting }}>\mathrm{Q}_{\text {sumur resapan, }}$ ini berarti debit banjir yang terdapat pada wilayah studi setelah penerapan sumur resapan dapat mengurangi debit banjir, dengan demikian di lahan yang penduduknya padat (perkotaan) dianjurkan membuat sumur resapan pada setiap rumah/bangunan sebagai salah satu upaya pencegahan banjir. Menurut Gemilang, G. (2013), proses alih fungsi lahan dari lahan pertanian atau hutan ke perumahan akan dapat menimbulkan dampak negatif, apabila tidak diikuti oleh upaya-upaya menyeimbangkan kembali fungsi lingkungan (seperti pembuatan sumur resapan). Disisi lain dipicu oleh pengembangan fisik bangunan rumah yang terlalu pesat ke arah horizontal yang menyebabkan tidak adanya lagi area terbuka sebagai resapan air, sehingga air yang meresap ke dalam tanah menjadi kecil dan memperbesar volume aliran air permukaan.

\section{KESIMPULAN}

Nilai koefisien aliran permukaan wilayah studi yaitu, 0,771 , tingginya nilai aliran permukaan tersebut menyebabkan berkurangnya kemampuan permukaan tanah dalam meresap air hujan. Dari hasil analisis debit banjir ( $Q p)$ pada tahun 2015 cenderung meningkat pada tahun berikutnya $\left(\mathrm{Q}_{\text {eksisting }}<\mathrm{Q}_{\text {rencana }}\right)$ yang berakibat pada timbulnya kejadian banjir. Perubahan pemanfaatan ruang pada sektor perekonomian di jalan Sudiman Kota Dumai cenderung meningkat dari tahun 2001, 2011 hingga 2015. Namun pengelolaan infrastruktur (drainase) tidak optimal, kondisi drainase mampat/ tersumbat dan ukurannya tidak sesuai. Salah satu cara penanggulangan banjir berwawasan lingkungan dengan membuat sumur resapan. Hasil analisis debit banjir dengan menggunakan sumur resapan didapatkan hasil $\mathrm{Q}_{\text {eksisting }}>\mathrm{Q}_{\text {sumur }}$ resapan. 


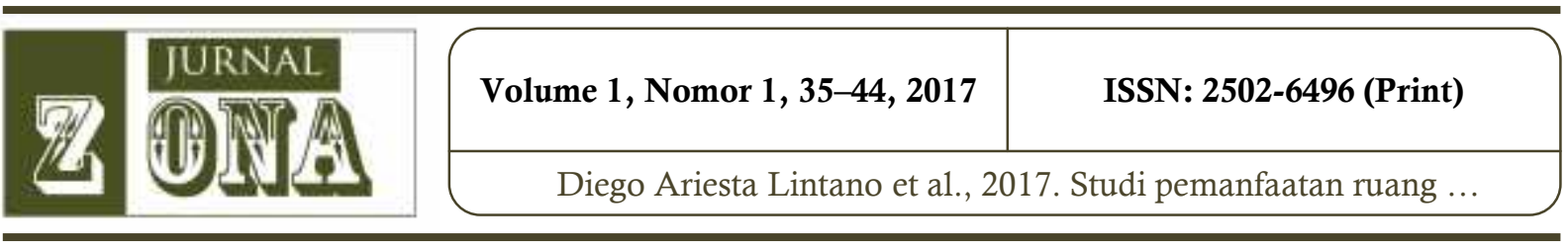

\section{UCAPAN TERIMAKASIH}

Penulis menyampaikan terimakasih kepada seluruh pihak yang membantu dalam kelancaran penelitian ini.

\section{DAFTAR PUSTAKA}

Affann, F. M. 2014. Analisis Perubahan Penggunaan Lahan Untuk Permukiman dan Industri dengan Menggunakan Sistem Informasi Geografis (SIG). IKIP Veteran Semarang.

Gemilang, G. 2013. Kajian Sumur Resapan Dalam Mereduksi Debit Banjir Pada Kawasan Perumahan Anugerah Lestari Kuala Gumit, Langkat. Teknik Sipil USU.

Handayani, Y.L, Hendri. A dan Suherly. H, 2007. Pemilihan Metode Intensitas Hujan Yang Sesuai Dengan Karakteristik Stasiun Pekanbaru. Universitas Riau. Teknik Sipil 8 (1) : 1 - 15.

Rachman, R. A., Suhardjono, S., \& Juwono, P. T. 2014. Studi Pegendalian Banjir Di Kecamatan Kepanjen Dengan Sumur Resapan. Universitas Brawijaya, Malang. Teknik Pengairan, 5 (1) : 79.

Soplanit, R dan Silahooy, Ch. 2012. Dampak Perubahan Penggunaan Lahan Terhadap Aliran Permukaan, Aliran Bawah Permukaan dan Aliran Dasar Di Das Batugajah Kota Ambon. Fakultas Pertanian Universitas Pattimura Ambon.Agrologia 1 (2) : 152 - 162.

Wendika, D., Soeryamassoeka, S. B., \& Yuniarti, E. 2012. Pengaruh Perubahan Tata Guna Lahan Terhadap Besarnya Debit (Q) Pada Suatu Kawasan (Studi Kasus Pasar Flamboyan).Universitas Tanjungpura. Teknik Sipil, 12(2).

Widayanti, R. 2010. Formulasi Model Pengaruh Perubahan Tata Guna Lahan Terhadap Angkutan Kota Di Kota Depok. Jakarta 